\title{
Not carious lesions: the challenge of the multidisciplinary diagnosis
}

\author{
Lesões não cariosas: o desafio do diagnóstico multidisciplinar \\ Simone de Macedo Amaral', Ernani da Costa Abad², Katlin Darlen Maiaa ${ }^{3}$, Sérgio Weyne ${ }^{4}$, Mariana dos Passos Ribeiro Pinto
Basílio de Oliveira ${ }^{5}$ Inger Teixeira de Campos Tunãs ${ }^{6}$.
}

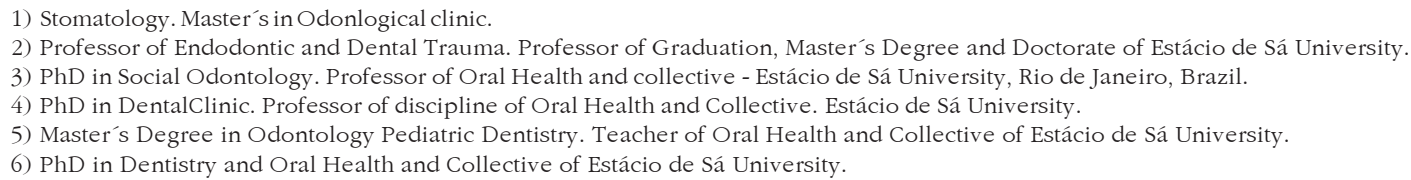

Mailing address: Simone de Macedo Amaral - Master's Degree in Odontology, Estácio de Sá University - 580 Alfredo Baltazar da Silveira, Av. - cobertura - Recreio dos Bandeirantes - Rio de Janeiro / RJ - Brazil - Zip-code: 22790-701 - Telephone: (+55 21) 2497-8988 / 2493-8894 - Fax: (+55 21) $2497-8950$ - Cell: (+55 21) 9956-8576 -E-mail: simacedoamaral@ hotmail.com

Article received in 2010 April $15^{\text {th }}$. Article approved in 2011 September $19^{\text {th }}$

\section{SUMMARY}

Introduction: The loss of the teeth surface or not carious lesion, is a physiological process that occur during the aging, but can be considered as pathological when the degree of destruction creates functional problems, aesthetic or dental sensibility. Many factors can contribute in part, but not necessarily simultaneously or equally as the cause of the not carious lesions. Although the cases of attrition (attrition, abrasion, corrosion and abfraction) are commonly discussed as independent alterations, in most of the times the loss of the teeth surface is the result of a combination of factors. One of the greatest challenges is to identify or quantify the influence of factors like the excessive consumption and abusive of drugs and acid substances, environmental factors and intrinsic etiologic agents such as gastro esophageal reflux. The immediate treatment must be directed for the resolution of sensibility and from pain; however, the investigation of the cause is essential.

Objective: The objective of this work is, through the literature review; help the many medical specialties to identify correctly the etiologic factors of not carious lesions.

Keywords: dental attrition, dental abrasion, dental corrosion.

\section{RESUMO}

Introdução: A perda da superfície dos dentes ou lesão não cariosa, é um processo fisiológico que ocorre com o decorrer do envelhecimento, mas pode ser considerado patológico quando o grau de destruição cria problemas funcionais, estéticos ou de sensibilidade dentária. Diversos fatores podem contribuir em parte, mas não necessariamente simultânea ou igualmente como causa das lesões não cariosas. Apesar dos casos de desgaste (atrição, abrasão, erosão, abfração) ser comumente discutidos como alterações independentes, na maioria das vezes a perda da superfície dos dentes é resultado de uma combinação de fatores. Um dos grandes desafios é identificar ou quantificar a influência de fatores como o consumo excessivo e abusivo de drogas e substâncias ácidas, fatores ambientais e agentes etiológicos intrínsecos como o refluxo gastresofágico. O tratamento imediato deve ser direcionado para a resolução da sensibilidade e da dor, entretanto, a investigação da causa é primordial.

Objetivo: O objetivo deste trabalho é, através de uma revisão da literatura, auxiliar as diversas especialidades médicas a identificar corretamente os fatores etiológicos das lesões não cariosas.

Palavras-chave: atrito dentário, abrasão dentária, erosão dentária. 


\section{INTRODUCTION}

The dental structure can be lost after its formation by many factors besides the most common case related to the caries disease or traumatic fractures. The enamel crown destruction may be initiated by abrasion, attrition, erosion or abfraction may begin on the dentin surfaces, or from the internal or external cementum resorption. The majority of the researchers believe that the prevalence of dental abrasion is increasing and it can be in part be explained by a greater awareness of clinicians, maintenance of natural teeth longer and a diet with greater quantity of acids $(1,2,3,4)$

The objective of this work is, through a literature review and critical analysis of the authors, aware Professionals linked to the health area about the importance of recognizing the signs in the oral cavity which can be of greater help to a differential diagnosis of various systemic pathologies, behavior changes and gastric disorders allowing multidisciplinary control of the etiological factors of noncarious lesions and its effective treatment.

\section{LITERATURE REVIEW}

Any person who possess natural tooth can develop dental abrasion, but many patients is unaware of its consequences till it reaches to an advanced phase. The prevalence of abrasion lesion increases with aging and affects in its majority the individual of masculine gender. Most studies of prevalence of enamel abrasion involve more children than adults and shows that it is common, affecting more than of $60 \%$ of involved while the prevalence of the exposure of dentin varies between 2 to $10 \%$. It is a physiological process which occurs during the aging, although it may be considered pathological when its destruction level creates functional problems, esthetics or dental sensitivity $(1,3,5,6,7)$.

\section{Concept and clinical characteristics of noncarious lesions: Abrasion, attrition, erosion and abfraction}

The classical concept of Abrasion is a process of demineralization or pathological loss of the dental structure or restoration, free from bacterial plaque which occurs slowly, gradual and progressive due to the harmful habits. The cervical areas are the most affected, reaching the hard tissues of teeth and promoting many times dentinal sensitivity, exposition and pulp necrosis $(3,4)$.

Attrition is defined as physiological attrition of the teeth surface or restoration caused by contact of teeth with

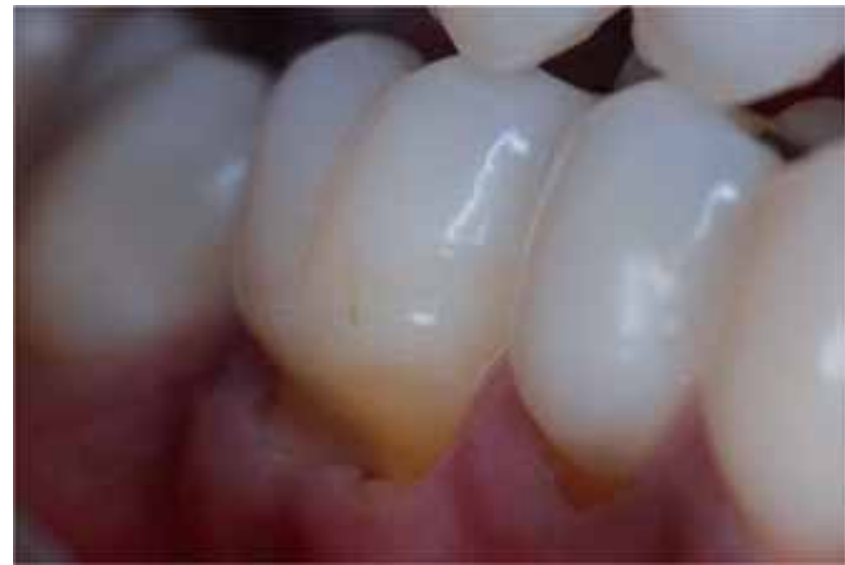

Figure 1. Abrasion - Note the dentin exposure and radicular.

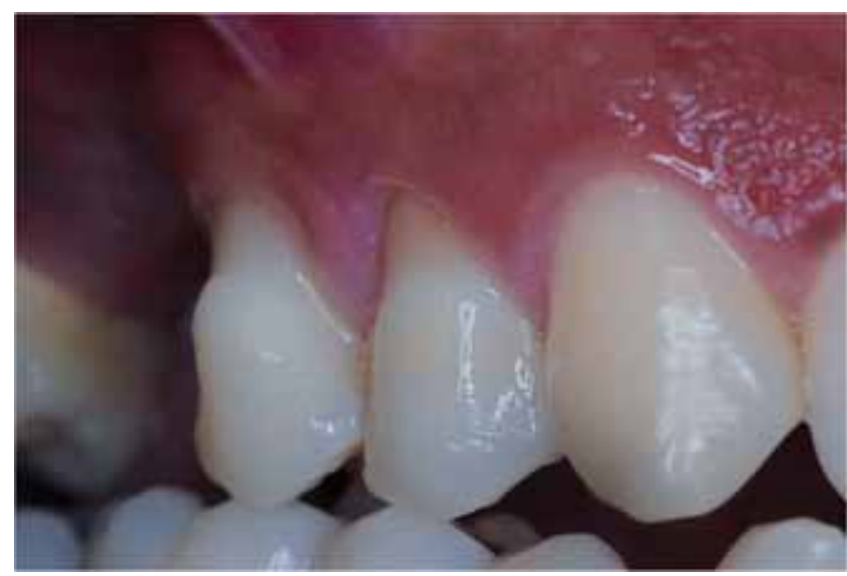

Figura 2. Abfraction with a certain abrasion level - Presence of malocclusion. Premature contacts of superiors and inferiors pre molars.

another during the chewing process or to function may occur in both deciduous and in permanent dentition. Most frequently we find occlusal surfaces, incisal and lingual of the maxillary anterior teeth and buccal of lower teeth $(1,3)$ (Figure 3).

Erosion has been described as pathological loss, progressive of dental structure caused by chemical process without involvement of bacterial action. Characteristically erosion is caused by exposition to acids provenient from beverages, fruit juice, wines, sporty beverages, all of kinds of soft drinks, vinegar, organic acids, specially lactic, citric and malic used in food industry and it can be exemplified by the clinical picture, Figure $4(1,2,3,4,8)$. The buffering effect of saliva may be overwhelmed by hyposalivation and excess of acid. The salivary glands hypofunction should be investigated, as well as bulimia, diabetes, use of medicines, regurgitation voluntary or involuntary, heartburn, hiatal hernia. The dental erosion from exposure to gastric 


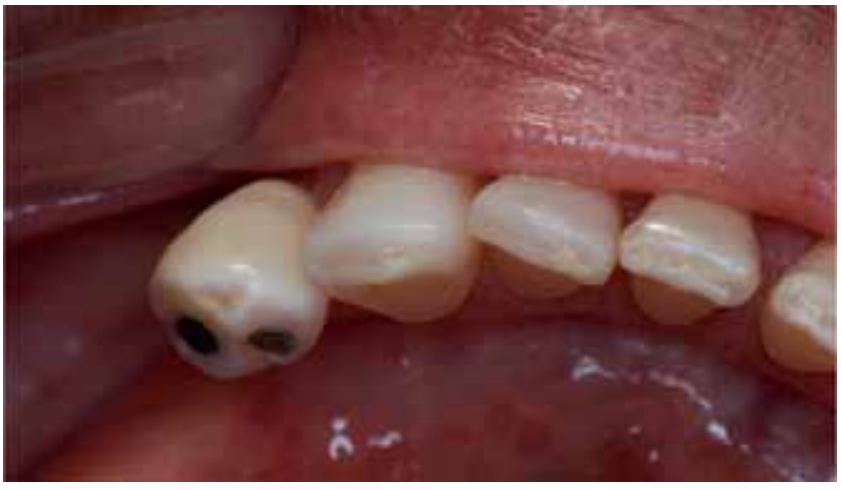

Figura 3. Attition and Erosion - Presence of islet amalgam. Enamel brightness loss in the occlusal and incisal region.

secretions is called perymolisis $(2,3,4)$. The abfraction is the loss of dental surface of the tooth at cervical areas by tensional and compressive forces secondary to the teeth bending by excessive occlusal load which when applied eccentrically to the teeth, the tension is concentrated on the cervical fulcrum, leading to the angle that can break out the enamel crystals chemical bonds at cervical areas. The abfraction can affect only one tooth and clinically it presents in wedge-shaped usually deep and with defined border. This type of lesion has greater incidence on the inferior tooth due to their smallest crown diameter at the cervical region. The abfraction is an example of lesion noncarious which affects the cervical region and it does not occur exclusively due to acid dissolution and the mechanical action of abrasive agents (Figures 1 and 2 ). This phenomenon may be worsened by the abrasion caused by aggressive brushing when the enamel once damaged can be easier to be removed by erosion or abrasion $(1,3,7,9)$.

\section{Etiological factors of noncarious lesions}

The etiology of the noncarious lesions may be multifactorial influenced by extrinsic factors (diet, medication), intrinsic factors (gastroesophageal reflex, frequent vomit typical of bulimia), mechanical dental detrition due to association of traumatic brushing associated to abrasive dentifrices and consumption of acid substances, use of legal or illegal drugs, besides of mechanical process resulting from harmful habits such as the frequent use of abrasive substances, dental bleaching without Professional supervision, habits of putting pencil between the tooth, tooth-picks, cable pipe, hair pin, nail biting, cutting line, tooth brush and dental floss misuse $(1,4,5,7,9,10,11,12,13$, 14).

The most common extrinsic factors are found in our diet. The great part of the fruits, juices, soft-drinks and others carbonated beverages - including the variants

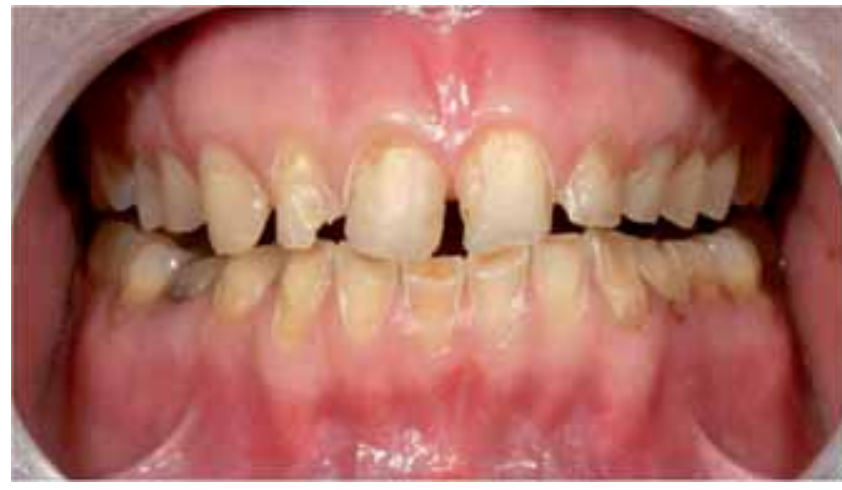

Figura 4. Abrasion by carbonated beverage and attrition by bruxism - Wear caused by the excessive consumption of cola soft drink. Patient with bruxism.

without sugar and some milk beverages with low $\mathrm{pH}$. A pH of up to 5.5, approximately is enough to weaken and demineralize the enamel surface, whereas to the dentin, a $\mathrm{pH}$ of 6.5 or lower, it has the same harmful effect, depending on the other factors as titrated acidity and contents of the products consumed: calcium, phosphate and fluoride of $(1,5,8,9,12)$. At the latest decades, it has been a significant increase in the consumption of acid in the beverages such as soft-drinks and fruit juices ready for use. It is necessary to warn to the fact of these substances being offered increasingly early in the infant nutrition through the use of bottles $(4,9)$.

The weakening process of tooth due to the acid usually it is attenuated by the saliva action, due to the presence of calcium, but the frequent e prolonged contact with acid substances leaves few time to remineralization. In this weakened state, the enamel is prone to wear of dental abrasive action and of brushing $(4,5,8)$. A decrease in $\mathrm{pH}$ of the liquids that bathes the dental elements may be caused directly by the consumption of acid fruits and beverages or indirectly by the ingestion of fermentable carbohydrates which allows a production of acid by the bacteria from the bacterial plaques. With the decrease in $\mathrm{pH}$, the solubility of enamel apatite increases dramatically. Simple calculations reveal that the decrease of a unit within the $\mathrm{pH}$ range from seven to four gives origin to a seven times greater in the solubility of hydroxyapatite. The clinical photography attached (fig. 4) is a good example of consequences of the abusive consumption of soft-drinks based on cola $(4,9)$.

The apatite solubility is affected by $\mathrm{pH}$ due to: the concentration of hydroxyl is inversely proportional to the hydrogen concentration and the concentration of phosphate ion complex depends of the $\mathrm{pH}$ of the solution. Studies suggest that the critical $\mathrm{pH}$ varies between 5,2 and 5,5, however this value depends on the concentrations of calcium and phosphate in the saliva $(6,8,9,14)$. 
When the saliva is subsatured from hydroxyapatite may still remain supersaturated with fluoroapatite. In $\mathrm{pH}=4$ saliva is subsaturated from both apatites, therefore loses the mineralizing ability. We can deduce that the $\mathrm{pH}$ value is one of the most important factors to be considered on a liquid diet. Other factors which must be considered are the present acid type and the acid level of ionic dissociation $(9,12)$.

The intrinsic factors, the more common cause is the erosion related to gastroesophageal reflux and regurgitation , and it affects more than $60 \%$ of people at some point in their lives. Associated to the low $\mathrm{pH}$ and gastric juice, the enamel and dentin destruction is frequently more severe than that caused by extrinsic factors $(1,9)$.

Substance abuse as a topical bleaching for vital tooth without Professional supervision, medicines (antidepressants, antihypertensives, anticonvulsants) continued use of vitamins, and legal drugs may be associated to the pathological dental wear. Several drugs are responsible for hyposalivation and only to cite an example, chewable tablets of vitamin $\mathrm{C}$ can low $\mathrm{pH}$. The application of cocaine paste in the cervical third of anterior teeth and the Methamphetamine consumption and lysergic acid should also be investigated $(2,13,15)$.

\section{How brushing and the use of toothpaste can affect the process of noncarious lesions?}

According to some researchers the brushing technique is not important to the appearance of abrasive lesions. A laboratorial investigation stated that it would take 2.500 years using a toothbrush alone to remove 1 millimeter from the teeth enamel and it would take 100 years using a combination of toothpaste and brush to remove 1 millimeter of enamel. The combination of toothpaste with produced acids in the same quantity would cause wear in 2 year $(1,7,9,11)$.

The abrasion caused by brushing it may be also influenced by a diet rich with food with acid $\mathrm{pH}$ may be related to the method, hardness of the brush filaments and shape of the endings of the filaments. The brushing trauma cannot cause direct gingival retraction but it may wear the teeth and the Cementoenamel Junction, which origins the cementum reduction, epithelial adherence reduction and alveolar bone loss induce to more gingival retraction, besides this it was identified that abrasion is significantly greater in linear brushing when compared to the rotative increasing its frequency it will result in an increase in the number of pathological wear. Despite of the soft brushes being less abrasives than the hard ones it can cause pathological wear when used with acid toothpaste non- fluoridated, since they retain more toothpaste for a longer time $(1,7,9)$.

By definition, the toothpaste contains abrasive agents with the purpose to remove stains and other deposits on the dental surface. Different formulas has different abrasive agents, some more than others. The toothpaste abrasivity depends on the size, form and quantity of the abrasive particles present in the toothpaste, being the toothpastes abrasivity commonly described as REA (relative enamel abrasivity) and RDA (relative dentine abrasivity) $(7,11)$. The relative dentine abrasivity (RDA) is a numerical scale, which indicates the abrasivity level and it is useful to compare distinct toothpastes. A value of RDA more elevated shows that a formula is more abrasive. The $\mathrm{pH}$ variation allowed for toothpastes ( $\mathrm{pH}$ 4-10) may constitute a cause for concern about the tooth wear due to chemical erosion, although virtually all of the products around the world have coefficients of $\mathrm{pH}$ above the level which may cause demineralization ( $\mathrm{pH}$ 5,5 for enamel, $\mathrm{pH}$ 6,5 for dentin) or, alternatively, the level of fluoride balances the effect of low $\mathrm{pH}$. The high values ADR of the toothpastes origin an increase to the dentin abrasion. In the toothpastes with similar RDA values, the abrasion is greater in toothpaste with low concentration of fluorides. The fluoride toothpaste gives greater protection for dental wear and an interaction between fluoride toothpaste and brushing, twice a day, Implies a 30\% decrease in erosion.

\section{The dentin hypersensitivity may be directly tied to the noncarious process lesions?}

The dentin hypersensitivity is characterized by a brief and acute pain, caused by the dentin exposure, in response to thermal stimuli, evaporative, tactile, osmotic or chemical may not assigned to any other damage or pathology. The evidences obtained from extracted teeth shows that in order to the hypersensitivity occur, the dentin must be exposed and the network of dentinal tubules opened in a way to allow the fluid movement due to the received stimulation, in fact, this is the case $(6,10,11)$

If the brushing using abrasive toothpaste may or may not begin the dentin hypersensitivity is a question that can be sustained by some scientifical evidences, although with origin mainly in laboratorial studies and, in lower level, study in humans. Many toothpaste seem to remove immediately layer of dentin smear to expose the tubules over a relatively short period, equivalent to days of brushing $(7,10,11)$.

Studies in vitrosuggest that this effect elapses from the abrasion and detergency systems contained in the 
product. We could say that this discussion shows that all of the toothpastes are etiological facts in the dentin hypersensitivity, but it is not necessarily so. Certain formulas, although remove a layer of dentin smear, after it causes a narrowing of the dentinal tubules presumably through a process of abrasive smears. Some toothpaste removes a layer of dentinal smear and then closes the tubules with inert abrasive particles. The products which contain artificial silica with non-ionic detergent seem to be the most effective in the pathological wear process: the frequent use of sodium lauryl sulfate, an anionic detergent, seem to prevent the adhesion of artificial silica to the dentin, probably by ionic competition (10).

Curiously, at least the enamel, in study in vitro demonstrated that erosion, combined to attrition, significantly softened tooth wear. The authors' explanation was that the enamel contact surface became very irregular in neutral $\mathrm{pH}$ conditions, but too smooth with an erosive $\mathrm{pH}$ : the frictional forces would therefore be markedly reduced. It is obvious that, if the dentin be exposed only by attrition or by attrition combined with erosion, there could be the dentinal hypersensitivity. But, once more, this would imply to the wear open the tubular system. The opening of the tubules would occur almost certain and would be consistent to the presentation of few individuals who frequently complaint of with dentinal hypersensitivity on the occlusal surface which shows the habit grinding tooth and the ingestion of great quantity of citrus fibrous fruits $(7,10,11)$.

To the point more common to dentinal hypersensitivity, the buccal and cervix zone, there are evidences, obtained mainly on studies in vitro and in situ, which shows that the chemical erosion has potential to locate and start lesions. In this way, studies in situ demonstrated that, in some individuals, having a liter of soft-drink a day, which is common in many countries, it could lead to the removal of one millimeter of enamel in few years. In the region buccal and cervical of tooth, this would mean that more than the enamel length at this moment. Beyond this, as already mentioned, the speed of enamel loss would be accelerated by regular brushing. The laboratorial investigation and $i n$ situ shows that, once the dentin is exposed, the acid beverages can remove a layer of dentinal smear, exposing the tubules after ingestion of clinical equivalent of small doses of an acid beverage $(6,9,10,12)$.

\section{Occupational exposure and dental erosion}

Date from the beginning of the century the first publications focusing the association between occupational exposure and manifestation of Stomatognathic System.
The studies of association between exposure to acid mists and dental erosion have been predominated in the dental research, relatively to other potential effects. Reports from specialized literature show that the occupational exposure to the acid substances, in its various physical forms (gases, vapors or mists), constitute important factor of risk to buccal pathologies, observing consistent results related to the dental erosion $(5,17,18)$. During review by British Dental Association (1959) initiative, about dental erosion in industry workers, identifies 11 references, between articles and theses, published at the period of 1915 to 1955 . The findings showed that the existence of positive association between exposure to industrial process which used acid products and dental erosion, with some of them presenting severe dental destruction and haggard $(17,18)$. Many authors evaluated this pathology, characterized by the dental structure demineralization due to the contact with chemical substances, found in elevated occurrence in workers exposed to inorganic acids used in some branches of industry, such as in metallurgy, steel industry, in battery factory etc $(2,5,9,16,17,18)$.

It was already reported that the occupation of wine tasters constitute in risk factor to dental erosion and that its severity was related to the time of service and also to the salivary flow and the buffering capacity of each individual. The association between salivary flow and the low buffering capacity accentuated the severity of erosive lesions significantly $(2,5,17,16)$.

\section{DISCUSSION}

All of the persons present certain dental wear lifelong, however, in certain individuals, this wear can reach pathological levels as a result of enamel loss, dentin exposure and consequently a situation of dentinal hypersensitivity $(9,10)$.

Whereas the brushing, with or without toothpaste, it seems cause a minimum wear to the enamel (in the absence of acids), circumstantial evidence relates the brushing to gingival retraction and the exposure of dentin $(9,10)$.

The possibility of dental acid erosion in people of developed nations is high, due to the level of consumption of acids beverages and foods, adding an intrinsic problem that increases the acid contact with dental tissue $(9,10,12,14,17,18)$.

Whereas a good oral hygiene prevents periodontal disease and caries, a dental brushing frequent and aggressive, especially if done immediately after meals rich in acid substances, can trigger dental abrasion, which results in 
irreversible loss of the most external layer of the enamel causing abrasion/ gingival retraction, enamel loss and cervical dentin exposure, causing many times dentinal hypersensitivity $(4,6,9,11)$.

Other processes of dental wear, namely attrition and chemical erosion, causing enamel loss and possible exposure of dentin, hence being result in a situation of dentinal sensitivity. Abrasion caused by certain toothpastes and the erosion caused by the action of the acids contained in the foods are capable to open the tubular system $(7,9)$.

The brushing technique is not important to the appearance of lesions but several authors agree that the brushing after meals should be delayed for many hours in order to allow the remineralization of the dental tissue. The evidences available relate the brushing with dental wear to beyond the improper cleaning; such wear will reach pathological proportions when combined to the predominant process of wear, the chemical erosion $(1,10,14,18)$.

Data available in the reviewed literature indicate that the abrasion and erosion act additively and synergistically in the wear process of enamel and dentin wear, raising the importance of correct diagnosis and control of the etiological factors only then initiate the most appropriate treatment $(1,7,9,14,18)$.

Regarding to dentin hypersensitivity, the nature of the most of data available here uses do not allow making an absolute statement, but in terms of probability, respecting the association among several factors involved in the process. There appear to be, however, evidences that suggest that the brushing and the dental wear constitute etiological factors in localization and initiation of dentin hypersensitivity $(6,10)$. As result, these processes need to be taken in account in order to define a strategy of control of dentin hypersensitivity.

It is, therefore, important to understand the multifactorial origin of lesions noncarious so that it can be initiated the investigation process of the related habits to the lesion and begin with prevent measures for erosion and for abrasion appreciating not only the changes in the oral hygiene as well as in the diet and behavior related to the lesion $(9,10,14,18)$.

\section{CONCLUSION}

Diagnose and determine the etiological factor of the noncarious lesions is essential to prevent its damages and it is so important as well as the decision to restore or not the affected tooth.

\section{BibLIOGRAPHIC REFERENCES}

1. Bartlett D. A new look at erosive tooth wear in elderly people. J Am Dent Assoc. 138, 2007:21s-25s.

2. Cardoso AC. Atlas clínica da corrosão do esmalte e da dentina. Ed. Quintessence, 2007:p.28, 29, 31.

3.Neville B W, Damm DD, Allen CM. Patologia oral \& maxilofacial. $3^{\underline{a}}$ ed; Rio de Janeiro: Guanabara Koogan, 2009:p.60-63.

4. Torres CP, Chinelatti MA, Gomes-Silva JM, Rizóli FA, Oliveira MA, Palma-Dibb RG, Borsatto MC. Surface and subsurface erosion of primary enamel by acid beverages over time. Braz Dent J. 2010, 21(4):337-45.

5. Almeida T F, Vianna MI P. O Papel da epidemiologia no planejamento das ações de saúde bucal do trabalhador. Saúde e Sociedade. 2005, 14(3):144-154.

6. Walters PA. Dentinal hypersensitivity: a review. The J of Contemp Dent Pract. 2005, 6(2) May, 2005.

7. Pires P, Ferreira JC, Silva MJ. Lesões de abrasão dentária: herança de uma escovagem traumática? Rev Port Estomatol Cir Maxilofac. 2008, 49:19-24.

8. Lodi CS, Sassaki KT, Fraiz FC, Delbem AC, Martinhon CC. Evaluation of some properties of fermented milk beverages that affect the demineralization of dental enamel. Braz Oral Res. 2010, 24(1):95-101.

9. Sobral MAP, Luz MAAC, Gama-Teixeira A, Netto GM. Influência da dieta líquida ácida no desenvolvimento de erosão dental. Pesqui Odontol Bras. 2000, 14(4):406410.

10. Sobral MAP, Netto NG, Garonete NN. Aspectos clínicos da etiologia da hipersensibilidade dentinária cervical. Rev Odontol Univ São Paulo. 1999, 13(2).

11. Addy M. Escovagem, desgaste dentário e hipersensibilidade dentinária estarão associados? Inter Dent J. 2005, 55(4):261-267.

12. Gambon DL, Brand HS, Nieuw Amerongen AV. Soft drink, software and softening of teeth - a case report of tooth wear in the mixed dentition due to a combination of dental erosion and attrition. Open Dent J. 2010, 4:198-200.

13. Ito Y, Momoi Y. Bleaching using 30\% hydrogen peroxide and sodium hydrogen carbonate. Dent Mater J. 2011, 30(2):193-8. 
14. Vasconcellos IC, Vasconcellos AC, Cunha DD. Erosão ácida dos dentes: um problema da atualidade. Riso. 2006 2(16):12-15.

15. Shetty V, Mooney LJ, Zigler CM, Belin TR, Murphy D, Rawson $\mathrm{R}$. The relationship between methamphetamine use and increased dental disease. J Am Dent Assoc. 2010 , 141(3):307-18.

16. Vianna MIP, Santana VS. Exposição ocupacional a névoas ácidas e alterações bucais: uma revisão. Cad. Saúde pública, Rio de Janeiro. 2001, 17(6):1335-1344.
17. Suyama Y, Takaku S, Okawa Y, Matsukubo T. Dental erosionandsulfuricion exposure levels in individuals working with sulfuric acid in lead storage battery manufacturing plant measured with mouth-rinse index. Bull Tokyo Dent Coll. 2010, 51(4):193-9.

18. Gandar BK, Truelove E. Diagnosis and management of dental erosion. The J of Contemp Dent Pract. 1999, 1(1):1623. 